\title{
SMALL SAMPLE DATING IN CHINA
}

\author{
WEIJIAN ZHOU, ${ }^{1}$ M. J. HEAD ${ }^{2}$ and LAURI KAIHOLA ${ }^{3}$
}

\begin{abstract}
The Xi'an Laboratory of Loess and Quaternary Geology has developed a small sample ${ }^{14} \mathrm{C}$ dating facility consisting of a Wallac 1220 Quantulus $^{\mathrm{TM}}$ liquid scintillation spectrometer, and a miniature benzene synthesis line based on the synthesis procedures used at the Australian National University (ANU). This line can produce ca. 0.3 -ml benzene samples, which are then measured for ${ }^{14} \mathrm{C}$ activity using $0.3-\mathrm{ml}$ Teflon vials developed by Wallac $\mathrm{Oy}$. The counting performance of the Quantulus ${ }^{\mathrm{TM}}$ spectrometer using $0.3-\mathrm{ml}$ vials has been evaluated, and a potential age limit of $\mathrm{ca} .45,000 \mathrm{BP}$ has been obtained for samples containing up to $250 \mathrm{mg}$ carbon. This dating facility fills the gap between large sample $(2.4-6 \mathrm{~g}$ carbon) and microsample ( $<1 \mathrm{mg}$ carbon) handling to form a ${ }^{14} \mathrm{C}$ dating method sequence.
\end{abstract}

\section{INTRODUCTION}

The establishment of a relatively accurate ${ }^{14} \mathrm{C}$ chronology for many of the well-defined loesspaleosol sequences in northern China is an important component of any investigation of global climate change over the past 30,000 yr. The carbon content of these sediments ranges between 1 and $2 \%$. Intensive agriculture has introduced a relatively high concentration of young water-soluble organic compounds, which are then adsorbed onto the clay component of the paleosols. Thus, it is advisable to subject the organic component of the paleosols to extensive pretreatment and chemical fractionation to obtain reliable ${ }^{14} \mathrm{C}$ ages (Head, Zhou and Zhou 1989; Zhou, Zhou and Head 1990; Zhou et al. 1992). The final components for dating are usually too small for conventional liquid scintillation counting (LSC). Because of the scarcity of ${ }^{14} \mathrm{C}$ accelerator mass spectrometry(AMS) facilities in China, and the expense of obtaining AMS dates from overseas, the concept of upgrading an existing radiometric ${ }^{14} \mathrm{C}$ dating facility to handle carbon sample sizes between 25 and $250 \mathrm{mg}$ is very attractive.

Polach et al. (1988) have documented LSC performance on very small samples (25-250 mg carbon) for a variety of vial types ranging from $0.3 \mathrm{ml}$ to $3.0 \mathrm{ml}$ using carefully diluted aliquots of a $200 \%$ modern standard. They found that, for samples containing $<250 \mathrm{mg}$ carbon, minivials produced more precise results than larger vials. For $0.3-\mathrm{ml}$ Teflon vials developed by Wallac Oy (Kaihola, Kojola and Heinonen 1992), a figure of merit (FM) of 11.9 was obtained by the ANU Radiocarbon Dating Research Unit, producing a theoretical dating limit of 43,230 BP for a 3000-min counting period (Polach et al. 1988). Further studies by Hogg (1992) have shown that the accuracy of results obtained using this type of vial falls within acceptable limits for samples containing 100-250 $\mathrm{mg}$ carbon. This method thus enables us to determine the ${ }^{14} \mathrm{C}$ activity of samples containing $250 \mathrm{mg}$ carbon with acceptable precision, even though the counting is slow.

\section{METHODS}

We decided that using a full-scale benzene synthesis apparatus for samples of $<250 \mathrm{mg}$ carbon decreased efficiency of preparation and yield of benzene. Thus, we designed a miniature system based on the procedures developed at the ANU Radiocarbon Dating Research Unit (Gupta and Polach,

\footnotetext{
${ }^{1}$ Xian Laboratory of Loess and Quaternary Geology, Chinese Academy of Sciences, P. O. Box 17, Xi'an, Shaanxi Province, China

${ }^{2}$ Quaternary Dating Research Centre, Research School Of Pacific Studies, Australian National University, Canberra, ACT 0200, Australia

${ }^{3}$ Marketing Department, Wallac Oy, P. O. Box 10, SF-20101, Turku, Finland
} 
1985). The miniature benzene synthesis apparatus also enabled us to keep possible memory effects to a minimum.

Because of the difficulty in transferring the sample benzene from the collection trap to a storage vial without incurring significant losses, actual yield measured was as low as $75 \%$, which is representative of a total yield of $c a .95 \%$. Sample benzene was added to the $0.3-\mathrm{ml}$ Teflon vials together with butyl PBD scintillant at a relative concentration of $15 \mathrm{~g} \mathrm{liter}^{-1}(0.0045 \mathrm{~g})$. It was found that the 0.3$\mathrm{ml}$ vial as supplied (Kaihola, Kojola and Heinonen 1992) tended to lose up to $1 \mathrm{mg}$ benzene by evaporation over a period of 7-8 days. The use of 2 Tuffbond silicone/Teflon seals instead of 1 caused benzene loss to be as low as $0.3 \mathrm{mg}$ per week. The vials were positioned for maximum quantum yield (Kaihola, Kojola and Heinonen 1992) by lining up a mark on each vial with a mark on the Quantulus sample lift mechanism. The value of the modern standard obtained as a mean of the two vials is $2.9853 \mathrm{cpm}$, and background is $0.07 \mathrm{cpm}$, giving an FM of 11.28 . With this value, the theoretical age limit for the vials is $43,270 \mathrm{BP}$, using the equations listed by Gupta and Polach (1985), and by Kaihola, Kojola and Heinonen (1992). These values were obtained with a counting efficiency of $88 \%$.This theoretical age limit compares favorably with that obtained by Polach et al. (1988).

\section{CROSS-CHECK SAMPLES}

To test the accuracy of the technique, a series of previously dated samples was collected from the ANU Laboratory and the Xi'an Laboratory archives. Table 1 shows the results. All samples were measured for $3000 \mathrm{~min}$, and are expressed as conventional ages (Stuiver and Polach 1977). To test whether the small sample ages are significantly different from the original ages obtained for the samples, the T statistic for one degree of freedom was calculated (Gupta and Polach 1985). Because $T$ has a chi-squared distribution, we can then use the relevant tables for one degree of freedom at the 95\% confidence level. $\mathrm{T}$ needs to be greater than 3.841 for the results to be significantly different.

TABLE 1. Comparison Between Small Sample Results and Dates Obtained Previously for the Same Sample

\begin{tabular}{|c|c|c|c|c|}
\hline Lab no. & $\begin{array}{c}\text { Age } 1(\mathrm{BP}) \\
(0.3 \mathrm{ml})\end{array}$ & Lab no. & Age 2 (BP) & T value* \\
\hline XLLQ-58 & $39,650 \pm 2210$ & XLLQ-58 & $30,930 \pm 320$ & 53.9 \\
\hline XLLQ-106 & $14,110 \pm 530$ & ANU-6393 & $14,000 \pm 1700$ & .004 \\
\hline XLLQ-336 & $5,330 \pm 180$ & XLLQ-336 & $5100 \pm 130$ & 1.073 \\
\hline XLLQ-9 & $2,410 \pm 130$ & XLLQ-9 & $2300 \pm 50$ & .624 \\
\hline XLLQ-120 & $2,340 \pm 130$ & XLLQ-120 & $2180 \pm 90$ & 1.024 \\
\hline XLLQ-14 & $2,470 \pm 130$ & XLLQ-14 & $2390 \pm 80$ & .275 \\
\hline XLLQ-13 & $2,460 \pm 130$ & XLLQ-13 & $2620 \pm 85$ & 1.061 \\
\hline XLLQ-483 & $29,660 \pm 680$ & ANU-5827 & $29,220 \pm 640$ & .222 \\
\hline XLLQ-484 & $18,390 \pm 450$ & ANU-4655 & $18,720 \pm 220$ & .178 \\
\hline XLLQ-485 & $10,560 \pm 160$ & ANU-6613 & $10,800 \pm 220$ & 1.528 \\
\hline XLLQ-486 & $6,255 \pm 150$ & ANU-7099 & $6150 \pm 80$ & .381 \\
\hline XLLQ-487 & $4,450 \pm 140$ & ANU-7852 & $4360 \pm 80$ & .312 \\
\hline XLLQ-489 & $3,550 \pm 140$ & ANU-5085 & $3130 \pm 80$ & 6.785 \\
\hline XLLQ-490 & $1,650 \pm 130$ & ANU-6088 & $1550 \pm 70$ & .459 \\
\hline XLLQ-491 & $220 \pm 140$ & ANU-5425 & $330 \pm 80$ & .465 \\
\hline
\end{tabular}

The small sample age for XLLQ-58 is significantly older than the previous result obtained, and the only explanation for this is the fact that further pretreatment was carried out before the sample was 
rerun (this was a sample of wood holocellulose). The small sample age would be considered to be the most reliable. The only other pair of results showing a significant difference is XLLQ-489 and ANU 5085. We have no explanation for the perceived difference in age other than the fact that this was a shell sample and there may be a small amount of heterogeneity in the sample. There may also have been exchange between shell carbonate and atmospheric $\mathrm{CO}_{2}$ since the original shell material was dated $c a .5 \mathrm{yr}$ earlier. For the remaining pairs, the T statistic is much less than the chi-squared value, indicating that the results are extremely close.

\section{CONCLUSION}

This exercise has indicated that the Xi' an Laboratory small sample facility for ${ }^{14} \mathrm{C}$ dating using liquid scintillation spectrometry can produce ${ }^{14} \mathrm{C}$ ages with precision comparable to other counting techniques.

\section{ACKNOWLEDGMENTS}

This project was supported by the NSF of China, Grant No. 48970163 . Steve Robertson, Zhou Mingfu and Jiang Yu provided much technical support. The authors would also like to thank Alan Hogg for his constructive review.

\section{REFERENCES}

Gupta, S. K. and Polach, H. A. 1985 Radiocarbon Practises at ANU. Canberra, Australian National University: $171 \mathrm{p}$.

Head, M. J., Zhou, W. J. and Zhou, M. F. 1989 Evaluation of ${ }^{14} \mathrm{C}$ ages of organic fractions of paleosols from loess paleosol sequences near Xian, China. In Long, A., Kra, R. S. and Srdoc, D., eds., Proceedings of the 13th International ${ }^{14} \mathrm{C}$ Conference. Radiocarbon 31 (3): 680-696.

Hogg, A. G. 1992 Assessment of 0.3-ml minivials for radiocarbon dating by liquid scintillation counting of benzene. In Long, A. and Kra, R. S., eds. Proceedings of the 14th International ${ }^{14} \mathrm{C}$ Conference. Radiocarbon 34(3): 389-393.

Kaihola, L., Kojola, H. and Heinonen, A. 1992 A minivial for small sample ${ }^{14} \mathrm{C}$ dating. In Long, A. and Kra, R. S., eds., Proceedings of the 14 th International ${ }^{14} \mathrm{C}$ Confer- ence. Radiocarbon 34(3): 402-405.

Polach, H., Kaihola, L., Robertson, S. and Haas, H. 1988 Small sample ${ }^{14} \mathrm{C}$ dating by liquid scintillation spectrometry. Radiocarbon 30(2):153-155.

Stuiver, M. and Polach, H. A. 1977 Discussion: Reporting of ${ }^{14} \mathrm{C}$ data. Radiocarbon 19(3): 355-363.

Zhou, W. J., An, Z. S., Lin, B., Xiao, J., Zhang, J. Z., Xie, J., Zhou, M. F., Porter, S. C., Head, M. J. and Donahue, D. J. 1992 Chronology of the Baxie loess profile and the history of monsoon climates in China between 17,000 and 6000 years BP. In Long, A. and Kra, R. S., eds., Proceedings of the 14 th International ${ }^{14} \mathrm{C}$ Conference. Radiocarbon 34(3): 818-825.

Zhou, W. J., Zhou, M. F. and Head, J. $1990{ }^{14} \mathrm{C}$ chronology of Bei Zhuang Cun sedimentation sequence since 30,000 years BP. Chinese Science Bulletin 35(7): 567572. 